\title{
Мороз M.O.
}

\section{ДЕТЕРМІНАНТИ ІНВЕСТИЦЙНОЇ БЕЗПЕКИ УКРАЇНИ}

\begin{abstract}
Наголомено на відсутності в теперішній час належного рівня інвестииійної безпеки Украӥни та однозначних підходів до очінки ї̈ детермінант $і$ комплексної оцінки стану ії формування в країні. Оцінено рівень валового нагромадження в ВВП Украӥни, зокрема, валового нагромадження основного капіталу. Проаналізовано стан освоєння капітальних інвестицій вітчизняними підприємствами за видами активів, економічної та промислової діяльності, регіонами й джерелами фінансування та акцентовано увагу на недоліках у цій сфері. Охарактеризовано залучення прямих іноземних інвестицій в Украӥну. 3'ясовано проблеми обліку притоку і запасів прямих іноземних інвестицій в Украйну. Зазначено вплив іноземних інвестицій як джерела притоку іноземної валюти в крайну не лите на інвестиційну безпеку Украӥни, а й на ї̈ валютну $і$ боргову безпеку. Виявлено негативний вплив девальвації наџіональної грошової одиниці та зростання сукупної заборгованості країни на ї̈ інвестиційну безпеку. Розглянуто стан вітчизняного банківського інвестиційного кредитування та причини його нерозвиненості. Досліджено динаміку основних показників, щчо характеризують стан інвестииійної сфери в Украӥні в 2010-2016 роках.
\end{abstract}

Ключові слова: валове нагромадження, інвестиції, капітальні інвестиції, прямі іноземні інвестиції, міжнародна інвестиційна позиція, інвестииійна безпека

Постановка проблеми. Ситуація із залученням інвестицій в українську економіку як внутрішніх, так i зовнішніх - критична, інвестори не мають впевненості у захищеності та прибутковості своїх інвестицій, оскільки за попередні роки вони втратили довіру до влади, а зараз до цього ще додається складна ситуація на Сході та економічна ситуація в країні загалом [5].

Тобто, говорити про сьогоденне забезпечення інвестиційної безпеки України не доводиться, що негативно позначається на стабілізації національної економіки, розв'язанні нагальних соціальних проблем, підвищенні іміджу нашої держави на міжнародній арені.

Аналіз останніх досліджень і публікацій. Окремі аспекти аналізу детермінант інвестиційної безпеки держави містяться в наукових працях таких дослідників, як: О. Барановський, Г. Берляк, Р. Бузін, І. Губенко, Н. Дацій, В. Кириленко, Д. Литвинов, О. Малютін, С. Пашова, М. Перзеке, С. Савелко, А. Сітарчук, Г. Харламова, Ю. Шеховцова. Однак й досі в економічній літературі відсутні як однозначні підходи до оцінки детермінант інвестиційної безпеки України, так і комплексна оцінка стану іiї формування в Україні.

Формулювання цілей статті. Мета статті полягає в оцінці окремих детермінант інвестиційної безпеки України, визначенні проблем, що існують у цій сфері.

(C) Мороз Максим Олександрович, аспірант ДВНЗ «Університет банківської справи», м.Київ, e-mail:mma588525@gmail.com
Опис основного матеріалу дослідження. На зростанні ВВП і підвищенні рівня інвестиційної безпеки позначається рівень валового нагромадження, зокрема, валового нагромадження основного капіталу (табл.1), оскільки за норми нагромадження менше $10 \%$ ВВП економічний розвиток відсутній. При цьому збільшення частки валового нагромадження в ВВП на $1 \%$ призводить до його зростання на $0,1 \%[1]$.

Наведені дані свідчать про наявність у 20122016 рр. можливостей для економічного розвитку. Втім, у 2013 р. зафіксований нульовий приріст ВВП, в 2012 р. він зріс лише на 0,2\%, 2016 р. $2,3 \%$, а в 2014-2015 його падіння становило $6,6 \mathrm{i}$ 9,8\% відповідно, що зумовлено анексією Криму і проведенням АTO, а також погіршенням кон'юнктури світових товарних ринків i зниженням ділової активності в Україні. А відтак зазначені можливості не були використані належним чином, що негативно позначилось і на рівні інвестиційної безпеки України.

Низька активність інвесторів $є$ одним 3 ключових індикаторів і чинником посилення макроекономічних дисбалансів та засвідчує неефективність економічної політики у 20142016 pp.[11].

Загалом освоєння капітальних інвестицій підприємств України останніми роками характеризується такими даними (табл.2).

За аналізований період щорічний обсяг освоєння капітальних інвестицій зріс в 1,7 раза. Причому їх освоєння відбувалось нерівномірно. Так, якщо в 2009-2012 спостерігалась висхідна тенденція, то в 2012-2014 - спадна, а 2014-2016 - 
знову висхідна. Найбільший приріст був найбільше падіння в 2014 р., що значною мірою зафіксований в 2011 р., що було наслідком виходу зумовлювалось анексією Криму і проведенням країни 3 фінансово-економічної кризи, а АТО.

Таблиця 1

Частка валового нагромадження в ВВП України, млн грн.*

\begin{tabular}{|l|c|c|c|c|c|}
\hline Показники & 2012 & 2013 & 2014 & 2015 & 2016 \\
\hline ВВП у фактичних цінах & 1404669 & 1465198 & 1586915 & 1988544 & 2383182 \\
\hline Приріст ВВП, \% & 0,2 & 0,0 & $-6,6$ & $-9,8$ & 2,3 \\
\hline Валове нагромадження & 305031 & 270895 & 212591 & 316841 & 512830 \\
\% до ВВП & 21,7 & 18,5 & 13,4 & 15,9 & 21,5 \\
\hline Валове нагромадження основного капіталу & 266795 & 247054 & 224327 & 269422 & 361030 \\
\% до ВВП & 19,5 & 16,9 & 14,1 & 13,5 & 15,1 \\
\hline
\end{tabular}

* Складено і розраховано автором за жерелом [7; 11]

Таблиця 2

Обсяги освосння капітальних інвестицій підприсмств України в 2009-2016 рр.*

\begin{tabular}{|l|c|c|c|c|c|c|c|c|}
\hline $\begin{array}{l}\text { Обсяг освоєння капіталь- } \\
\text { них інвестицій, } \\
\text { млрд грн. }\end{array}$ & 2009 & 2010 & 2011 & 2012 & 2013 & 2014 & 2015 & 2016 \\
\hline Темп приросту, \% & - & $-2,0$ & 37,4 & 13,0 & $-8,9$ & $-18,0$ & 24,5 & 19,4 \\
\hline
\end{tabular}

*Складено і розраховано автором за [13]

На наш погляд, обсяг освоєння капітальних інвестицій явно недостатній для забезпечення розширеного відтворення, переведення національної економіки на інноваційний напрям розвитку, особливо враховуючи наявний далеко не оптимальний розподіл таких інвестицій за сферами економічної діяльності.

Причому розбудова інноваційної економіки ускладнюється тим, що за 2010-2016 pp. капітальні інвестиції в промисловість зросли в 2,1 раза, тоді як в сільське і лісове господарство та мисливство - 4,6 раза, діяльність у сфері адміністративного та допоміжного обслуговування - 3,4 раза, операції з нерухомим майном - 2 рази ${ }^{1}$. Водночас, капітальні інвестиції в промисловості спрямовуються в основному в постачання електроенергії, газу, пари та кондиційованого повітря - 26,1\% від загального обсягу, добувну промисловість і розроблення кар'єрів - 19,1\%, виробництво харчових продуктів, напоїв, тютюнових виробів $-18,1 \% 2$. Тобто, лише ці три підгалузі акумулюють майже 2/3 усіх капітальних інвестицій.

У промисловості внаслідок неефективного розподілу інвестицій консервуються низькотехнологічна структура виробництва, сировинна орієнтація економіки, а відтак залежність від зовнішньої кон'юнктури. Економічне зростання не грунтується на оновленні технологій та інноваціях. Високий рівень зношення та вибуття основних фондів лише частково компенсується за

\footnotetext{
${ }^{1}$ Розраховано автором за [14]

${ }^{2}$ Розраховано автором за [15]
}

рахунок оновлення i пояснює, чому приріст інвестицій не забезпечує істотного розширення виробництва [10, с.92].

Нераціональним 3 огляду на вищезазначену спрямованість національної економіки $€$ й розподіл капітальних інвестицій за видами активів. Так, лише в житлові і нежитлові будинки та інженерні споруди в 2016 р. вкладено майже половину всіх капітальних інвестицій, тоді як інвестиції у нематеріальні активи становили лише $3,3 \%$, у т.ч. на програмне забезпечення та бази даних $-1,75 \%^{3}$.

Не додає інвестиційної безпеки Україні, на наше переконання, i розподіл капітальних інвестицій за іï регіонами в 2010-2016 роки. Причому насторожує й той факт, що в 2016 р. спостерігалось зниження обсягу освоєних капітальних інвестицій по окремих регіонах (Волинська, Закарпатська, Рівненська, Чернівецька, Івано-Франківська області). А в Тернопільській, Дніпропетровській, Вінницькій областях і в м. Києві індекс капітальних інвестицій був нижчим, ніж в середньому по Україні.

Варто зазначити, що капітальне фінансування розвитку інфраструктури є одним із найбільш перспективних напрямів підвищення інвестиційного потенціалу регіонів. Вагомим його резервом $\epsilon$ кошти Державного фонду регіонального розвитку, які спрямовуються на виконання інвестиційних програм i проектів регіонального розвитку (у т.ч. проектів співробітництва й добровільного об'єднання

\footnotetext{
${ }^{3}$ Розраховано автором за [13]
} 
територіальних громад), на створення інфраструктури індустріальних та інноваційних парків. Найбільше коштів цього фонду у 2015 р. отримали Дніпропетровська (169,4 млн грн., або 7,1 \% загального обсягу), Донецька (141,3 млн, або 5,9 \%), Харківська (133 млн, або 5,6 \%), Львівська (127,4 млн, або 5,4 \%), Вінницька (127 млн, або 5,3 \%), Івано-Франківська області (125,3 млн, або 5,3 \%) та м. Київ (154,2 млн, або 6,5\%), а найменше - Луганська область (20,5 млн грн., або $0,9 \%$ загального обсягу коштів). Загальний обсяг Державного фонду регіонального розвитку на 2016 р. становив 3 млрд грн.[2, с.288-289].

Не краща ситуація і з надходженням в Україну прямих іноземних інвестицій (ПІІ). Так, якщо у 2005-2008 pp. середньорічний приріст ПІІ в Україну становив \$6,63 млрд, то у 2009-2012 pp. уже \$4,7 млрд, тобто скоротився на 29\%. Після деякого пожвавлення у 2010-2011 рр. іноземне інвестування в Україну з 2012 р. сповільнилося.

Загалом за роки незалежності в економіку України наростаючим підсумком на початок 2017 p. надійшло лише \$37,66 млрд ПII (акціонерного капіталу). Більше того, 3 початку агресії у 2014-2015 рр. країна втратила понад чверть ПІІ 3 понад \$58 млрд, залучених у попередні 19 років[10].

Причому обсяг ПІІ (акціонерного капіталу) у $\$ 37,7$ млрд на початок 2017 р. був нижчим за аналогічні показники 2010-2015 рр. Крім того, в 2016 р. вперше 32010 р. було зафіксовано їх абсолютне зниження майже на $\$ 3$ млрд, хоча й вкладено їх було більше, ніж у 20142015 роках[12].

Водночас, за оцінками НБУ, приплив іноземних інвестицій в економіку України в 2016 р. становив $\$ 3,4$ млрд, зокрема «живими» грішми надійшли кошти на $\$ 1,1$ млрд, тоді як $\$ 2,3$ млрд - це насправді бухгалтерська операція 3 конвертації іноземними банками своїх кредитів перед материнськими банками в капітал[18]. Тобто - це кошти, не здатні примножити капітал. Така ситуація де-факто негативно позначається на інвестиційній безпеці України.

Поряд 3 цим, іноземні інвестиції як джерело притоку іноземної валюти в країну впливають не лише на інвестиційну безпеку України, а й на іiі валютну і боргову безпеку. Водночас, девальвація гривні та зростання сукупної заборгованості негативно впливає на інвестиційну безпеку.

Крім того, викликає певне занепокоєння i походження ПІІ в Україну. Так, на Кіпр, Нідерланди, РФ, Велику Британію, Віргінські острови (Брит.), Німеччину i Швейцарію припадало майже $3 / 4$ сукупного обсягу ПІІ, що надійшли в Україну за роки незалежності, у т.ч. майже третина - 3 офшорних територій, в які раніше був виведений вітчизняний капітал ${ }^{4}$. А за 2016 р. лідером за обсягом річних ПІІ, що надійшли в Україну, стала Росія - 37,8\%, Кіпр 9,7\%, Велика Британія - 9,2\%[25]. Водночас, на початок 2017 р. з України в економіку країн світу було інвестовано \$6,34 млрд[24].

На початку 2017 р. НБУ запровадив нову методику оцінки обліку запасів ПІІ відповідно до їх поточної ринкової вартості, що, на думку іï розробників, має наблизити їх вартість до реалій ринку та зменшити розбіжності в даних НБУ та Держстату. Такий крок був зумовлений тим, що, по-перше, внаслідок світової фінансовоекономічної кризи 2008-2009 рр. ринкова вартість активів підприємств, у т.ч. й банків, суттєво знизилася. Відсутність перегляду їх вартості призвела до того, що починаючи з 2010 р. частина запасів ПІІ відображалась за суттєво завищеною вартістю. По-друге, методологією 6-го видання Керівництва 3 платіжного балансу та міжнародної інвестиційної позиції (МВФ, 2009), яку НБУ застосовує з 2015 р., передбачено обов'язкову переоцінку вартості активів у разі суттєвих вартісних змін на фондовому ринку.

У результаті проведеного перерахунку вартості запасів ПІІ, врахованих за ціною останньої операції, з урахуванням їх ринкової вартості за 2010-2016 рр. встановлено, що їх вартість станом на початок 2017 р. зменшилася на $\$ 14,1$ млрд та становила \$48,9 млрд (проти $\$ 63$ млрд за попередньою оцінкою)[18].

Крім того, здійснена переоцінка дозволила зменшити різницю між даними НБУ та Держстату про запаси ПІІ з \$11,3 млрд до \$3,6 млрд

Станом на 31.12.2016 найвагоміші обсяги надходжень ПІІ були спрямовані до установ та організацій, що здійснюють фінансову та страхову діяльність $-\$ 10,32$ млрд, та підприємств промисловості - $\$ 9,55$ млрд

На інвестиційній безпеці України має позначатися розвиток ринку інвестиційного кредиту, рівень якого на сьогодні $\epsilon$ недостатнім.

Жодна з 21-ї бюджетної програми з надання кредитів 3 держбюджету в 2016 р. не виконана. Надано кредитів на суму 7,12 млрд грн., або 44,8\% плану, з яких 99,2\% - за рахунок кредитів (позик), що залучаються державою від іноземних держав, банків і МФО для реалізації інвестиційних програм (проектів). При цьому внаслідок неналежної організації впровадження інвестиційних проектів, зокрема недотримання підрядниками запланованих графіків робіт, тривалого погодження змін до контрактів і проведення конкурсних торгів відповідно до вимог кредиторів, а також незатвердження паспортів за

${ }^{4}$ Розраховано автором за [12] 
окремими бюджетними програми, вибірка коштів на їх реалізацію здійснювалася не в повному обсязі або взагалі не розпочата[6, с.28-29].

Вартість договорів фінансового лізингу, укладених за 2015 р., становила 6,241 млрд грн., а в 2016 р. - 9,754 млрд грн. При цьому вартість діючих договорів лізингу на початок 2017 р. дорівнювала 22,9 млрд грн.[23], що на 3,2 млрд грн. менше, ніж на початок 2016 р., і на 35,4 млрд грн. менше, ніж на початок 2015 p., що негативно характеризує розвиток цього сегменту вітчизняного ринку інвестиційного кредиту. Крім того, на початок 2017 р. спостерігалася тенденція зменшення частки довгострокових договорів лізингу. Вартість договорів, термін дії яких більше 5 або дорівнює 10 рокам, порівняно 3 аналогічною датою попереднього року, зменшилась на $11 \%$ (655,3 млн грн.), договори 3 терміном дії більше 10 років зменшились на $33,8 \%$ (437,5 млн грн.)[23].

Важливе значення в підвищенні рівня інвестиційної безпеки України належить банківському інвестиційному кредитуванню, яке може спрямовуватись на: реконструкцію/ модернізацію виробничих потужностей, будівництво і організацію нових виробництв.

Аналіз світового досвіду свідчить, що близько половини інвестицій у розвиток інфраструктури національних економік різних країн світу забезпечують інвестиційні банки, які спеціалізуються на банківських інвестиційних кредитах. В економічно розвинених країнах частка інвестиційних кредитів у сукупному обсязі кредитування економіки становить близько $70 \%$, в країнах, що розвиваються - близько $45 \%$ [22].

Однак цей сегмент інвестиційної сфери в нашій країні належним чином нерозвинений. Так, в 2010-2016 pр. частка кредитів банків та інших позик (а відтак, чисто банківських ще менше) в загальному обсязі капітальних інвестицій становила від 7,5 до $15,2 \%$. Причому найнижча частка була зафіксована в 2016 р., що зумовлено як вкрай незначним абсолютним обсягом таких кредитів, так і зростанням частки власних коштів підприємств (на які на початок 2017 р. припадало $3 / 5$ сукупного обсягу капітальних інвестицій) та місцевих бюджетів ${ }^{5}$.

В 2010-2012 pр. обсяг кредитів банків й інших позик зростав, їх приріст становив 16,8 млрд грн. Проте, в 2013-2015 pp. їх обсяги почали знижуватись і за три роки зменшились майже на 14 млрд грн. Лише в 2016 р. знову спостерігалось ix зростання на 6,4 млрд грн. При цьому найбільший приріст був зафіксований в 2011 р. -

\footnotetext{
${ }^{5}$ Розраховано автором за [16]
}

$60,1 \%$ та 2016 р. - 30,7\%, а найбільше зниження в 2014 p. $-37,4 \%$ і 2013 p. $-12,6 \%$.

Показники, які характеризують розвиток інвестиційного кредитування в Україні в 20092012 pp., свідчать, що в загальній структурі частка кредитів в інвестиційну діяльність, наданих нефінансовим корпораціям-резидентам, зменшилась із 19,13\% у 2009 р. до $14,72 \%$ у 2012 р., а у співвідношенні з ВВП України в 2010-2011 рр. порівняно з 2009-м спостерігалося не суттєве, але зменшення. Так, 2009 р. воно становило 9,69\%, a 2010 і 2011 pp. 7,87 та 7,01\% відповідно. Зростання відношення таких кредитів до ВВП спостерігалося лише 2012 р. і становило 8,08\%[26, с.356-357]. Тільки в 2013 р. змінилась тенденція зниження обсягів інвестиційного кредитування.

Характерними особливостями інвестиційного кредитування інноваційної діяльності є: нижчий розвиток банківського інвестиційного кредитування такої діяльності порівняно з інвестиційним кредитуванням в Україні загалом; надання кредитів великими банками - дочірніми структурами великих іноземних банків, які мають доступ до «довгих грошей»; кредит у діапазоні від 1,5 до 100 млн грн. банк може надати одноосібно, кредитування на більшу за цей розмір суму реалізується шляхом створення консорціуму 3 кількох банків; термін кредиту від 3,5 до 10 років, тобто проект має досягти самоокупності; власні інвестиції позичальника повинні складати від 15 до $30 \%$ усього бюджету проекту[21].

Здійснений автором аналіз статус-кво в даному сегменті свідчить, що нерозвиненість банківського інвестиційного кредитування зумовлена:

- недоступністю даних кредитів для багатьох господарюючих суб' єктів;

- значно вищими ризиками довгострокового банківського кредитування (внаслідок низької кредитоспроможності позичальників) за його нижчої дохідності, а відтак, високими вимогами банків до його забезпечення;

- відсутністю спеціальних інвестиційних кредитних інструментів НБУ, які б спрямовувались на рефінансування комерційних банків, задіяних в інвестиційному кредитуванні реального сектору національної економіки, а також державної підтримки інвестиційних проектів шляхом часткової компенсації відсотків за такими кредитами;

- певним програшем банківського інвестиційного кредитування у змаганні за клієнтів фінансовому лізингу, оскільки майно за лізинговою угодою не враховується на балансі лізингоодержувача, а його вартість не включа- 
ється в кредитну заборгованість, що поліпшує фінансові показники лізингоодержувача;

- формуванням портфеля цінних паперів вітчизняних банків за рахунок спекулятивних цінних паперів;

- відсутністю дієвих механізмів захисту кредиторів і позичальників при банківському інвестиційному кредитуванні;

- політичною нестабільністю в країні.

Так, на кінець травня 2017 р. 320 найбільших банків лише 8 надавали кредити на розвиток бізнесу в гривні, а середня ефективна ставка за кредитами становила 20,55\% (залежно від строку кредитування в межах 19,96\%-24,28\% річних. Максимальний строк кредитування становив 7 років.

За підсумком 2016 р. портфель цінних паперів банківської системи (табл. 3) збільшився на $64,9 \%$ і станом на 01.01.2017 р. відповідав 332,27 млрд грн. Обсяг ОВДП у власності банків протягом 2016 р. збільшився на 77,1\% до 312,47 млрд грн. Важливо зауважити, що за цей же період обсяг ОВДП у портфелі НБУ зазнав скорочення до 7,99 млрд грн. $(-2,1 \%)[3$, с.4].

Портфель цінних паперів банківської системи України в 2012-2016 pp. [19]

\begin{tabular}{|c|c|c|c|c|c|}
\hline Показник & 1.01.13 p. & 1.01.14 p. & $1.01 .15 \mathrm{p}$ & $1.01 .16 \mathrm{p}$. & $1.01 .17 \mathrm{p}$. \\
\hline \multicolumn{6}{|l|}{ Активи, млн грн. } \\
\hline $\begin{array}{l}\text { Загальні активи (не скориговані } \\
\text { під активні операції) }\end{array}$ & 1267892 & 1408688 & 1520817 & 1571411 & 1737272 \\
\hline Чисті активи & 1127192 & 1278095 & 1316852 & 1254385 & 1256299 \\
\hline Кредити надані & 815327 & 911402 & 1006358 & 965093 & 1005923 \\
\hline Вкладення в цінні папери & 96340 & 138287 & 168928 & 198841 & 332273 \\
\hline Частка вкладень в цінні папери в загальних активах, \% & 7,6 & 9,8 & 11,1 & 12,7 & 19,1 \\
\hline Частка вкладень в цінні папери в чистих активах,\% & 8,6 & 10,8 & 12,8 & 15,9 & 26,5 \\
\hline
\end{tabular}

Додатковим негативним чинником, що створює дефіцит кредитних ресурсів для реального сектору, $\epsilon$ перерозподіл тимчасово вільних коштів банків з кредитного портфеля у портфель боргових цінних паперів держави. Високі, на рівні $20 \%$ річних, процентні ставки за ОВДП знижують зацікавленість банків у кредитуванні реального сектору економіки (інвестиції банків на купівлю ОВДП зросли 3 86 млрд грн. станом на 1 січня 2016 р. до 142 млрд грн. станом на 1 липня 2016 р.). Разом з тим, банки розмішують надлишкову ліквідність у короткострокових (7 та 14 днів) сертифікатах НБУ за ставками 19-20 \% річних. При цьому загальний обсяг коштів, витрачених на купівлю цінних паперів НБУ, також мав тенденцію до зростання - 33 млрд грн. станом на 1 січня 2014 р. до 89 млрд грн. - на 1 січня 2016 р. Наявність двох зазначених інструментів безпечного та прибуткового інвестування ресурсів банків (ОВДП - для довгострокових вкладень, сертифікати НБУ - для короткострокових) на тлі проблемності більшості позичальників реального сектору провокує збереження дефіциту банківського кредитування для останніх у середньостроковій перспективі $[2$, c.316].

Крім того, слід наголосити на мізерній частці в загальному обсязі капітальних інвестицій коштів держбюджету, яка в 2010-2016 pр. коливалась на рівні 1,2-7,2\%, а також іноземних інвесторів - 1,73,0\% відповідно.

В оцінці інвестиційної безпеки України важливе місце належить і врахування ступеню зносу основних засобів, оскільки ії рівень поряд 3 іншими індикаторами визначається і відношенням обсягу інвестицій до вартості основних фондів (у $\%)$. Так, за останніми даними, основні фонди в Україні зношенні майже на $2 / 3$, що, безумовно, істотно знижує рівень їі інвестиційної безпеки.

Загалом динаміка основних показників, що характеризують стан інвестиційної сфери в Україні, виглядає таким чином (табл.4).

Оскільки 3 моменту капіталовкладень до одержання віддачі у вигляді зростання темпів виробництва існує певний часовий лаг, то доцільно забезпечувати випереджальний приріст інвестицій порівняно з приростом ВВП. Утім, враховуючи той факт, що в 2010, 2013-2014 капітальні інвестиції взагалі знижувались, говорити про наявність необхідного рівня капіталомісткості, тобто критичної маси інвестицій, спроможної забезпечити економічне зростання в Україні, поки що не доводиться.

Обсяг ПІІ у розрахунку на одного жителя в Україні упродовж 2010-2014 рр. коливався в діапазоні \$848-1183, а в 2016 р. взагалі знизився до $\$ 881$ і залишався найменшим серед країн Свропи і СНД, зокрема, в Чехії цей показник перевищував \$7 тис., у Болгарії - \$6 тис., у Казахстані - \$3 тис.[4]. 
Таблиця 4

Динаміка основних показників, що характеризують стан інвестиційної сфери

в Україні в 2010-2016 рр.

\begin{tabular}{|l|c|c|c|c|c|c|c|}
\hline \multicolumn{1}{|c|}{ Показники } & $\mathbf{2 0 1 0}$ & $\mathbf{2 0 1 1}$ & $\mathbf{2 0 1 2}$ & $\mathbf{2 0 1 3}$ & $\mathbf{2 0 1 4}$ & $\mathbf{2 0 1 5}$ & $\mathbf{2 0 1 6}$ \\
\hline ВВП України, млрд грн. & 1079,3 & 1300,0 & 1404,7 & 1465,2 & 1586,9 & 1988,5 & 2383,2 \\
\hline Темпи приросту ВВП, \% & 4,1 & 5,2 & 0,2 & 0,0 & $-6,6$ & $-9,8$ & 2,3 \\
\hline ВВП України, млрд дол. & 136,42 & 163,16 & 175,78 & 183,31 & 131,81 & 90,62 & 93,81 \\
\hline Частка валового нагромадження у ВВП, \% & 20,8 & 22,4 & 21,7 & 18,5 & 13,4 & 15,9 & 21,5 \\
\hline $\begin{array}{l}\text { Інвестиції в основний капітал (у фактичних } \\
\text { цінах), млн грн. }\end{array}$ & 180575,5 & 241286,0 & 273256,0 & 249873,4 & 219419,9 & 273116,4 & 359216,1 \\
\hline $\begin{array}{l}\text { Темпи приросту інвестицій в основний } \\
\text { капітал, \% }\end{array}$ & $-2,0$ & 37,4 & 13,0 & $-8,9$ & $-18,0$ & 24,5 & 19,4 \\
\hline $\begin{array}{l}\text { Інвестиції в основний капітал (без коштів } \\
\text { іноземних інвесторів), млрд дол. }\end{array}$ & 22,3 & 29,6 & 33,6 & 30,7 & 18,0 & 12,1 & 14,5 \\
\hline Інвестиції в основний капітал до ВВП, \% & 16,7 & 18,6 & 19,5 & 17,1 & 13,8 & 13,7 & 15,1 \\
\hline $\begin{array}{l}\text { Прямі іноземні інвестиції (ПІІ) в Україну, } \\
\text { млрд дол. }\end{array}$ & 39,0 & 45,4 & 48,2 & 51,7 & 53,7 & 40,7 & 37,7 \\
\hline ПІІ в Україну до ВВП, \% & 28,6 & 27,8 & 27,4 & 28,2 & 40,7 & 44,9 & 40,2 \\
\hline ПІІ в Україну на 1 особу, дол. & 848 & 991 & 1057 & 1134 & 1183 & 949 & 881 \\
\hline $\begin{array}{l}\text { Сумарний обсяг капітальних інвестицій } \\
\text { (без коштів іноземних інвесторів) і ПІІ, } \\
\text { млрд дол. }\end{array}$ & 61,3 & 75,0 & 81,8 & 82,4 & 71,7 & 52,8 & 52,2 \\
\hline $\begin{array}{l}\text { Сумарний обсяг капітальних інве-стицій } \\
\text { (без коштів іноземних інве-сторів) і ПІІ до } \\
\text { ВВП,\% }\end{array}$ & 44,9 & 46,0 & 46,5 & 45,0 & 54,4 & 58,3 & 55,7 \\
\hline Середньорічний курс долара & 7,94 & 7,97 & 7,99 & 7,99 & 11,88 & 21,84 & 24,1 \\
\hline
\end{tabular}

* Складено і розраховано автором за $[7 ; 11 ; 12 ; 20]$

Водночас, слід зазначити, що зростання (табл.5) за вкрай незначного обсягу ПІІ, обсягів інвестування останніми роками використання яких необхідне для модернізації відбувається переважно за рахунок інших вітчизняного виробництва, оскільки супроінвестицій (торговельні, банківські й інші кредити воджується трансфером сучасних технологій й (від МФО і МЕО, урядів зарубіжних країн), досвіду.

фінансовий лізинг, угоди з іноземною валютою)

Таблиця 5

Динаміка міжнародної інвестиційної позиції України

(за методологісю КПБ6), на початок року, млн дол. [8]

\begin{tabular}{|l|l|l|l|l|l|l|l|}
\hline & $\mathbf{2 0 1 1}$ & $\mathbf{2 0 1 2}$ & $\mathbf{2 0 1 3}$ & $\mathbf{2 0 1 4}$ & $\mathbf{2 0 1 5}$ & $\mathbf{2 0 1 6}$ & $\mathbf{2 0 1 7}$ \\
\hline \multicolumn{1}{|c|}{ АКТИВИ } & & & & & & & \\
Прямі інвестиції & 6548 & 6960 & 7867 & 7998 & 7967 & 7787 & 7942 \\
Портфельні інвестиції & 94 & 108 & 173 & 176 & 188 & 173 & 96 \\
Інші інвестиції & 90798 & 99840 & 109627 & 107800 & 105075 & 102147 & 96700 \\
\hline $\begin{array}{l}\text { ПАСИВИ } \\
\text { Прямі інвестиції }\end{array}$ & 52872 & 59035 & 65276 & 67204 & 52587 & 47393 & 48858 \\
Портфельні інвестиції & 20085 & 21806 & 26765 & 35956 & 33032 & 29854 & 29737 \\
Інші інвестиції & 94141 & 99698 & 101345 & 100135 & 88681 & 85184 & 80056 \\
\hline
\end{tabular}

Отже, в Україні відсутня синхронізація регіонів і держави в фінансових і матеріальних інтересів суб'єктів інвестиційних відносин для ресурсах та об'єктах інтелектуальної власності, забезпечення в країні розширеного відтворення; достатній для повноцінного забезпечення їх реструктуризації та формування інноваційної життєдіяльності i поступального розвитку. моделі розвитку національної економіки, Об'єкти інвестування характеризуються низькою оптимального розподілу інвестицій по регіонах і інвестиційною привабливістю. В країні відсутні галузях господарського комплексу, надійності і інвестиційні доктрина, стратегія і політика, ефективності інвестицій. Спостерігається спрямовані на формування i ефективне асиметрія між інвестиційними попитом i використання інвестиційного потенціалу пропозицією, обсягами інвестицій і зростанням учасників інвестиційних процесів, створення ВВП, внутрішніми і іноземними інвестиціями, інвестиційних резервів національної економіки, обсягами і структурою інвестицій в регіонально- протидію непродуктивному відпливу капіталу за галузевому розрізі). Залишається незадоволеним межі країни, впровадження цивілізованого інвестиційний попит вітчизняних суб'єктів режиму дивестицій (вилучення інвестицій), господарювання, домогосподарств, галузей забезпечення сприятливого інвестиційного господарського комплексу, секторів економіки, клімату, запобігання викликам i загрозам в 
інвестиційній сфері і зниження ризиків реалізації інвестиційних проектів.

Висновки i перспективи подальших досліджень. Таким чином, можна зробити висновок, що статус-кво в сфері капітальних інвестицій та ПІІ не відповідає сформульованій автором сутності інвестиційної безпеки, під якою, на наше переконання, слід, зокрема, розуміти: досягнення реструктуризації та формування інноваційної моделі розвитку національної економіки, оптимального розподілу інвестицій по регіонах i галузях господарського комплексу, надійності і ефективності інвестицій; рівень задоволення інвестиційного попиту вітчизняних суб'єктів господарювання, домогосподарств, галузей господарського комплексу, секторів економіки, регіонів і держави в фінансових i матеріальних ресурсах та об'єктах інтелектуальної власності, достатній для повноцінного забезпечення їх життєдіяльності і поступального розвитку; інвестиційну привабливість об'єктів інвестування.

А відтак, потребують подальшого розвитку дослідження детермінант інвестиційної безпеки України для розробки й реалізації адекватних заходів з підвищення іiї рівня.

\section{ПЕРЕЛІК ВИКОРИСТАНИХ ДЖЕРЕЛ}

1. Алексеева Л. В. Юридическая психология / Л. В. Алексеева. - М.: Проспект, 2010. - 312 с.

2. Аналітична доповідь до Щорічного Послання Президента України до Верховної Ради України «Про внутрішне та зовнішнє становище України в 2016 році». - К. : НІСД, 2016. - 688 с.

3. Аналітичний огляд банківської системи України за результатами 2016 року. - К.: Національне рейтингове агентство «Рюрік», 2017. -22 с.

4. Багатостороннє агентство з гарантування інвестицій [Електронний ресурс]. - Режим доступу : http://www.miga.org.

5. Беззуб I. Іноземні інвестиції в українській економіці / І. Беззуб[Електронний ресурс]. - Режим доступу: http://www.nbuviap.gov.ua/index.php?\%20option

6. Висновки про виконання Закону України «Про Державний бюджет України на 2016 рік». - К.: Рахункова палата України, 2017. - 50 с.

7. Валовий внутрішній продукт[Електронний ресурс]. - Режим доступу: http://www.ukrstat.gov.ua/operativ/2016/vvp/vvp_kv/vvp_kv_u/arh_vvp_kv.html

8. Динаміка міжнародної інвестиційної позиції України[Електронний ресурс]. - Режим доступу: https://bank.gov.ua/doccatalog/ document?id=19208379

9. Економічна безпека держави: сутність та напрями формування : монографія / Л. С. Шевченко, О. А. Гриценко, С. М. Макуха та ін. / за ред. д-ра екон. наук, проф. Л. С. Шевченко. - Х.: Право, 2009. - 312 с.

10. Економічна безпека України в умовах гібридної агресії. - К.: НІСД, 2017[Електронний ресурс]. - Режим доступу: http://www.niss.gov.ua/articles/

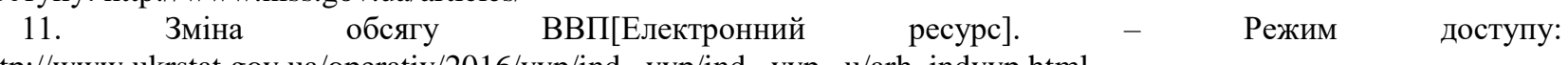
http://www.ukrstat.gov.ua/operativ/2016/vvp/ind_vvp/ind_vvp_u/arh_indvvp.html

12. Інвестиційна діяльність в Україні[Електронний ресурс]. - Режим доступу: http://www.me.gov.ua/Documents/List?lang=uk-UA\&tag

13. Капітальні інвестиції за видами активів за 2010-2016 роки[Електронний ресурс]. - Режим доступу: http://www.ukrstat.gov.ua/

14. Капітальні інвестиції за видами економічної діяльності за 2010-2016 роки[Електронний ресурс]. - Режим доступу: http://www.ukrstat.gov.ua/

15. Капітальні інвестиції за видами промислової діяльності за 2010-2016 роки[Електронний ресурс]. - Режим доступу: http://www.ukrstat.gov.ua/

16. Капітальні інвестиції за джерелами фінансування за 2010-2016 роки[Електронний ресурс]. - Режим доступу: http://www.ukrstat.gov.ua/

17. Національний банк запровадив нову методику оцінки запасів прямих іноземних інвестицій[Електронний pecypc]. - Режим доступу: https://www.bank.gov.ua/ control/uk/publish/article?art_id=46129890

18. НБУ про інвестиції: за рік «живими» грошима надійшов тільки мільярд[Електронний ресурс]. - Режим доступу: https://www.epravda.com.ua/ news/2017/03/3/622268/

19. Основні показники діяльності банків[Електронний ресурс]. - Режим доступу: https://bank.gov.ua/control/uk/publish/article?art_id=34661442

20. Офіційний курс гривні до іноземних валют, встановлений НБУ, середній за період[Електронний ресурс]. - Режим доступу: http://www.bank.gov.ua

21. Пашова С. М. Банківське інвестиційне кредитування інноваційної діяльності в Україні: автореф. дис. на здобуття наукового ступеня канд. екон. наук: спец.: 08.00.08 - гроші, фінанси і кредит / С. М. Пашова. -Київ, 2013. $-19 \mathrm{c}$.

22. Перзеке М. Б. Розвиток банківського інвестиційного кредитування в Україні: автореф. дис. на здобуття наукового ступеня канд. екон. наук: спец. 08.00 .08 - гроші, фінанси і кредит / М. Б. Перзеке. - Суми, 2014. - 22c. 
23. Підсумки діяльності фінансових компаній, ломбардів та юридичних осіб (лізингодавців) за 2016 рік[Електронний ресурс]. - Режим доступу: https://nfp.gov.ua/files/17_Dep_Repetska/FK_4\%20\%D0\%BA\% D0\%B2_2016.pdf

24. Прямі інвестиції (акціонерний капітал) [Електронний ресурс]. - Режим доступу: http://www.ukrstat.gov.ua/

25. Прямі інвестиції (акціонерний капітал) із країн світу в економіці України у 2016 році[Електронний pecypc]. - Режим доступу: http://www.ukrstat.gov.ua/

26. Сітарчук А.Ю. Сучасний стан банківського інвестиційного кредитування в Україні: проблеми і шляхи його розв’язання / А.Ю.Сітарчук // Соціально-економічні проблеми сучасного періоду України. Проблеми інтеграції України у світовий фінансовий простір. - 2013. - №1. - С.355-360.

\section{REFERENCES}

1. Alyeksyeyeva L.V. (2010) Legal psychology. M.: Prospekt.

2. Analytical report to the Annual Address of the President of Ukraine to the Verkhovna Rada of Ukraine "On the internal and external situation of Ukraine in 2016". - K. : NISD,. -688 p.

3. Analytical review of the banking system of Ukraine by results of 2016 (2017). K.: National rating agency "Rurik". 22 p.

4. Multilateral Investment Guarantee Agency. Retrieved from: http://www.miga.org

5. Bezzub I. Foreign investment in the Ukrainian economy. Retrieved from: http://www.nbuviap.gov.ua/index.php?\%20option

6. Conclusions on the implementation of the Law of Ukraine "On the State Budget of Ukraine for 2016". - K.: Accounting Chamber of Ukraine, 2017. - 50 p.

7. Gross Domestic Product. Retrieved from http://www.ukrstat.gov.ua /operativ/2016/vvp/vvp_kv/vvp_kv_u/arh_ vvp_ kv.htm

8. Dynamics of the International Investment Position of Ukraine. Retrieved from: https://bank.gov.ua/doccatalog/ document?id=19208379

9. Shevchenko L.S., Hrytsenko O.A., Makukha S.M. and others (2009). Economic security of the state: the essence and directions of formation: a monograph by ed. Dr. Econ. Sciences, prof. Shevchenko L.S. Kh.: Pravo, 312.

10. Economic security of Ukraine in conditions of hybrid aggression. - K.: NISD, 2017. Retrieved from: http://www.niss.gov.ua/articles/

11. Change in the volume of GDP. Retrieved from: http://www.ukrstat.gov.ua/operativ/2016/vvp/ind_ vvp/ind_ vvp_u/arh_indvvp.html

12. Investment activity in Ukraine Retrieved from: http://www.me.gov.ua/Documents/List?lang=uk-UA\&tag

13. Capital investments by types of assets for 2010-2016 Retrieved from: http://www.ukrstat.gov.ua/

14. Capital investments by types of economic activity for 2010-2016 Retrieved from: http://www.ukrstat.gov.ua/

15. Capital investment by types of industrial activity for 2010-2016 Retrieved from: http://www.ukrstat.gov.ua/

16. Capital investments by sources of financing for 2010-2016 Retrieved from: http://www.ukrstat.gov.ua/

17. The National Bank has introduced a new methodology for estimating foreign direct investment stocks Retrieved from: https://www.bank.gov.ua/control/uk/publish/article?art_id=46129890

18. NBU on investment: only a billion for the year has been received as "living" money. Retrieved from: https://www.epravda.com.ua/news /2017/03/3/622268/

19. Main indicators of banks' activities. Retrieved https://bank.gov.ua/control/uk/publish/article?art_id=34661442

20. The official exchange rate of hryvnia to foreign currencies, set by the NBU, the average for the period. Retrieved from: http://www.bank.gov.ua

21. Pashova S. M. (2013). Banking investment crediting of innovative activity in Ukraine: the author's abstract. dis. for the academic degree of Cand. econ. Kyiv.

22. Perzeke M. B. (2014). Development of bank investment crediting in Ukraine: the author's abstract. dis. for the academic degree of Cand. econ. Sumy.

23. Results of activity of financial companies, pawnshops and legal entities (lessors) for 2016 Retrieved from: https://nfp.gov.ua/files/17_Dep_Repetska/FK_4\%20\%D0\%BA\% D0\%B2_2016.pdf

24. Direct investments (share capital). Retrieved from: http://www.ukrstat.gov.ua/

25. Direct investments (share capital) from the countries of the world in the economy of Ukraine in 2016. Retrieved from: http://www.ukrstat.gov.ua/

26. Sitarchuk A.Yu. (2013). The current state of bank investment lending in Ukraine: the problems and ways of its solution. Socio-economic problems of the modern period of Ukraine. Problems of Ukraine's Integration into the World Financial Space. №1, 355-360.

Одержано 15.09.2017 p. 